\title{
FIG4 wt Allele
}

National Cancer Institute

\section{Source}

National Cancer Institute. FlG4 wt Allele. NCI Thesaurus. Code C124944.

Human FIG4 wild-type allele is located in the vicinity of $6 \mathrm{q} 21$ and is approximately $134 \mathrm{~kb}$ in length. This allele, which encodes polyphosphoinositide phosphatase protein, is involved in polyphosphoinositide metabolism. Mutation of the gene is associated with amyotrophic lateral sclerosis 11, Yunis-Varon syndrome, Yunis-Varon syndrome, bilateral temporooccipital polymicrogyria, and Charcot-Marie-Tooth disease, type 4J. 